Volume 2 Issue 2, September 2017: pp. 1-10. Copyright @ LamLaj. Faculty of Law, Lambung Mangkurat University, Banjarmasin, South Kalimantan, Indonesia. ISSN: 2502-3136 | e-ISSN: 2502-3128. Open Access at: http: / /lamlaj.ulm.ac.id/web/

\title{
MEDIATION IN COMMERCIAL COURT AS EQUAL PROTECTION BETWEEN DEBTORS AND CREDITORS
}

\author{
Mulyani Zulaeha \\ Faculty Of Law, Lambung Mangkurat University \\ Jln. H, Hasan Baseri Banjarmasin 70123 Indonesia \\ Telepon/Fax: +62-5113307877,E-mail:mulyani.zulaeha@yahoo.co.id
}

Submitted: 21/09/2017; Reviewed:23/09/2017; Accepted: 25/09/2017

\begin{abstract}
Mediation as a way of dispute resolution through negotiation process to achieve agreement of the parties assisted by mediator. It is considered as a form of dispute resolution that can meet the parties 'wishes, reducing the time and cost. It wants a dispute was resolved through the peace of the parties as outlined in the agreement. Moving from the weakness of peace as contained in Act No. 37/2004, then the mediation empowerment in the Commercial Court as a breakthrough and steps taken to create an equal protection between debtors and creditors (especially prospective debtors). The empowerment of mediation in the Commercial Court is in line with the policy direction and strategy of legal development contained in Presidential Regulation No. 2/2015, especially civil law enforcement, namely the resolution of civil cases is performed by encouraging the optimization of mediation process in court and simplification of civil procedure is expected to encourage the efficiency of civil resolution and give positive contribution to the improvement of national economy.
\end{abstract}

Keywords: Mediation; Commercial Court; Legal Protection; Debtors; Creditor

\section{INTRODUCTION}

The philosophy of bankruptcy is a mechanism of distributing assets in fair and equitable way to creditors related to the circumstances of not paying the debtor because its inability to perform the obligations. ${ }^{1}$ The essence of bankruptcy is the inability of debtor to pay the debt. Meanwhile, for debtors who

1 M. Hadi Shubhan. 2009. Hukum Kepailitan: Prinsip, Norma dan Praktik di Peradilan. Jakarta: Kencana Prenada Media Group. page. 23 still have the ability to pay the debt, should be given the protection so that the debtor is not bankrupt ${ }^{2}$ without inflict the creditor's inter-

2 Conditions of debtor bankrupt as in Article 2 paragraph (1) of Act No. 37/2004 is considered very easy, hence many debtors (companies) with large assets declared bankrupt only with insignificant debt. This occurs because under Article 8 Paragraph (4) stating that "the petition for bankruptcy must be granted if there is a fact or condition that proves simply that the condition to be declared bankrupt in the form of a debtor 
ests.

Peace as a solution that can be done by debtors and creditors to solve the problem of debt. However, the mechanisms of peace as contained in Article 144 and 222 of Act No. 37 of 2004 concerning Bankruptcy and Abandonment of Debt Payment (State Gazette of the Republic of Indonesia of 2004 No. 131, Supplement to State Gazette of the Republic of Indonesia No. 4443) hereinafter referred to as Act No. 37/2004). Both of these provisions have not provided protection against debtors, especially the prospective corporate debtor as result of the bankruptcy. ${ }^{3}$ According to Article 144 of Act No. 37/2004, peace can be made by the debtor after the commercial court has

has two or more creditors and does not pay off at least one debt already due date and can be billed has been fulfilled. The elucidation of Article 8 paragraph (4) states, "that fact or proven condition to be simple is the fact that two or more creditors and facts of debt is due date and not paid. The difference in the amount of debt as declared by the petitioner bankrupt and petitioned bankruptcy does not preclude the bankruptcy." If the conditions are met, the judge "must declare bankrupt," not "can declare bankruptcy," so that this will harm the debtor, especially the debtor who has the ability to pay.

3 The term prospective in Act No. 37/2004 contained in the General Elucidation section of the principle of business continuity stating that: in this law there is a provision which enables prospective debtor companies to continue." But Act No. 37/2004 does not provide further definition of the intended prospective. The concept of prospective (in the context of the company) is defined as a healthy company, i.e if the company is included in the liquid and solvable categories. Liquidity shows the ability of the company to meet its debt obligations in the short term. While, solvable is the ability of the company to meet its debt obligation in the long term. See Mulyani Zulaeha. (2016). Konsep Kepailitan Yang Memberikan Perlindungan Hukum Terhadap Debitor Perusahaan Yang Prospektif. Dissertation. Malang: Faculty of Law, Brawijaya University, page. 253. passed the decision of bankruptcy, and according to Article 222 of Act No. 37/2004, peace within the framework of abandonment of debt payment (PKPU - Penundaan Kewajiban Pembayaran Utang). Article 144 of Act No. 37/2004 states that "the bankrupt debtor is entitled to offer a peace to all creditors" and Article 222 of Act No. 37/2004 states that "debtors are unable or predicts may not be able to continue repaying their debts that have been due date and may be collected, may apply for the abandonment of debt payment, with the intention to propose a peace such offering partial payment or overall to the creditor."

Peace taken after the debtor declared bankrupt is not relevant to the goal of peace. It in bankruptcy should be interpreted as an effort to avoid the debtor especially prospectively declared bankrupt without neglecting its obligations to the creditors. But in the context of Article 144 of Act No. 37/2004, the peace after the debtor declared bankrupt is not an attempt to avoid bankruptcy, but only as an attempt debtor get an extension of time to make the payment.

Peace through the mechanism of PKPU as stated in Article 222 of Act No. 37/2004 is a form of protection especially for debtors who cannot or predict will not be able to continue paying their debts, are in a state unable to pay the debt but request to be given an extension of time to pay, because they still have hope to be able to pay if given the extension time. But this way is also not a means to protect the debtor. This is because there are some weaknesses in the procedure of PKPU which is very thick protection only to creditors, namely;

1. Debt as a requirement of the appeal of PKPU must first be done by debt recon- 
ciliation between debtor and creditors; this is difficult because concurrent creditor which amounted to more than one and its reconciliation must be done by correcting the evidence of debt owned by each party.

2. The time period provided does not provide an opportunity for the debtor to maximize the assets held to make the debt repayment. The deadline of extension provided shall be subject to mutual agreement with the concurrent creditors.

3. There is a regulation regarding the cancellation of peace or PKPU as the authority of creditor even though PKPU' decision has been permanent.

PKPU that submitted by the debtor as stipulated in Article 222 of Act No. 37/2004, it can be a shortcut to bankrupt debtor if:

a. The debtor is not present to appear in court held by the court at a maximum period of 45 days since the pronouncement of PKPU (Article 225 paragraph (5) jo paragraph (4) Act No. 37/2004), then the Commercial Court shall state the debtor is bankrupt in the same trial.

b. Within a maximum period of 45 days the creditors have not been able to vote on the peace plan at the request of the debtor (Article 228 paragraph (5) jo Article 225 paragraph (4) Act No. 37/2004), so that the Commercial Court cannot determine permanent PKPU, then the debtor is declared bankrupt.

c. The period of PKPU expires, because the creditors do not approve the granting of permanent PKPU or its extension has been granted, but up to 270 days has not been reached agreement on the peace plan (Article 230 paragraph (1) jo Article
228 paragraph (6) of Act No. 37/2004), then the Commercial Court must declare a bankrupt debtor based on a notification by a Supervisory Judge as administrator report by no later than the following day.

Article 235 paragraph (1) of Act No. $37 / 2004$ stipulates that "against the decision to abandonment the obligation to pay the debt cannot be filed any remedy."

From the weakness of peace contained in Act No. 37/2004, then the study in this paper is how the model of peace in the bankruptcy process that can provide equal protection between creditors and debtors. It aims to identify, analyzes and finds a model of peace that can provide equal legal protection between the prospective debtor and creditor.

\section{METHOD}

The research is normative-juridical; a legal research was conducted to get arguments, as well as new concepts to answer legal issues by reviewing and analyzing the provisions of legislation and other legal materials. The research approach uses a conceptual, statute and comparative approaches.

All primary and secondary legal materials that have been collected were classified and categorized according to this legal issue, and then the analysis of legal material is done prescriptively and analytically, to produce a precursor of what should be the essence of the research of law that holds the character of legal studies. The results of study and analysis by using legal logic, the grammatical and systematic legal interpretation, legal arguments and principles which in turn generate conclusions to legal issues to be answered.

\section{ANALYSIS AND DISCUSSION}

Mediation is a way of dispute resolution through negotiation process to get agreement 
of the parties assisted by mediator. It is considered as a form of dispute resolution that can meet the parties' wishes, reduces the time and cost. ${ }^{4}$ It is a process of negotiation assisted by a third party. ${ }^{5}$

Actually, the court connected mediation has been known since the period of Dutch colonial, which regulates the resolution of cases through peaceful, as regulated in Article 130 Paragraph (1) HIR (Herziene Indonesich Reglement, Staatsblad 1941)/Article 154 paragraph (1) RBG (Rechts Reglement Buitengewesten, Staatsblad 1927) as follows:

(1) If on the appointed day both parties arrive then the district court with the assistance of the chairman tries to reconcile them.

(2) If such a peace can be achieved, then during the session, a letter is made, in which the two parties are punished will fulfill the agreement, which letter will be enforced and will be executed as a common decision.

(3) Such a decision shall not be allowed an appeal.

(4) In the period is attempting to reconcile the two parties, it is necessary to use an interpreter so that such article rules are followed for that purpose.

The provisions of Article 130 of the HIR/154 RBG indicate that the resolution of disputes through the peace is part of the dispute resolution process in the court.

Article 130 HIR/154 RBG does not

4 See the Supreme Court R.I. 2005. Naskah Akademis Mahkamah Agung RI Tahun 2005 tentang Pembaharuan Sistem Peradilan. Jakarta: Mahkamah Agung RI.

5 Prosiding Mahkamah Agung RI. 2005. Mediasi dan Court Annexed Mediation. Jakarta: Mahkamah Agung RI dan Pusat Pengkajian Hukum. page 33. mention directly the term mediation, but the means mentioned in the article are generally similar to mediation, i.e the resolution of a case peacefully between the parties assisted by a third party. The application of Article 130 $\mathrm{HIR} / 154 \mathrm{RBG}$ in the practice of judicial proceedings is deemed ineffective, as it is only a recommendation for peace and is formalistic, as is seen in Article 130 paragraph (1) HIR, that: "if on the appointed day both parties arrive then the district court with the assistance of the chairman tries to reconcile them," so that the judicial sterility in producing a resolution through peace is not as a result of distortion of lawyers but attached to judges who put forward the formalistic nature. ${ }^{6}$

Responding to the weakness of the implementation of Article $130 \mathrm{HIR} / 154 \mathrm{RBB}$ in the court, the Supreme Court first issued the Supreme Court Circular Letter (SMEA) ${ }^{7}$ No 1 of 2002 on First Level Court Empowerment to Implementing Peace Agencies (former Article $130 \mathrm{HIR} / 154 \mathrm{RBB}$ ). Evaluation is always done by the Supreme Court regarding the effectiveness of mediation empowerment in court. Successively until 2016, the Supreme Court has issued several Supreme Court Regulations (PERMA), ${ }^{8}$ namely: PERMA No. 2/2003 dated 11 September 2003 on

6 D.Y. Witanto. 2011. Hukum Acara Mediasi Dalam Perkara Perdata Di Lingkungan Perdailan Umum dan Peradilan Agama Menurut PERMA No. 1 Tahun 2008 Tentang Prosedur Mediasi Di Pengadilan. Bandung: Alfabeta, page 66.

7 Surat Edaran Mahkamah Agung (SEMA) is a form of circulation from the chairman of Supreme Court to all levels of the judiciary whose contents are guidance in the administration of a more administrative judiciary.

8 Peraturan Mahkamah Agung (PERMA) is a form of regulation from the chairman of Supreme Court to all jurisdictions whose contents constitute provisions of a legal nature. 
Mediation Procedures in the Court; PERMA No. 1/2008 on Mediation Procedures in the Court; and lastly on 1 February 2016 the Supreme Court issued PERMA No. 1/2016 on Mediation Procedure in the Court as a substitute of PERMA No. 1/2008 on Mediation Procedures in the Court.

The issuance of SEMA and PERMA as a basis for integrating mediation into the judiciary and aims to optimize the system of cases resolution peacefully, as well as the consideration that mediation is one of the quicker and cheaper processes and may provide access to the parties to the dispute for equitable or satisfactory resolution over the dispute encountered. In addition, the integration of the mediation process into the judicial system can strengthen and maximize the function of judicial institutions that are decided (adjudicative). ${ }^{9}$

PERMA No. $1 / 2016$ as set forth in the consideration is a peaceful way to resolve disputes and may open broader access to the parties to obtain a satisfactory and just/fair resolution. Mediation as an instrument to improve access to justice as well as the implementation of simple, quick and low cost justice principles.

According to Article 4 paragraph (1) PERMA No. $1 / 2016$, mediation in the Commercial Court is not required for resolution through mediation first. Article 4 paragraph (2) PERMA No. 1/2016 states as follows:

Disputes that are exempt from resolution through mediation as referred to in paragraph (1) include:

a. Disputes whose examined in the hear-

9 Riduan Syahrani. 2004. Buku Materi Dasar Hukum Acara Perdata. Bandung: Citra Aditya Bakti, page 73. ing are determined by the time limit for completion, including:Disputes resolved through the procedures of the Commercial Court;

b. Disputes whose investigations are conducted in the absence of a plaintiff or defendant who has been properly summoned;

c. Reconvention and entry of a third party in a case (intervention);

d. Disputes concerning the prevention, rejection, cancellation and endorsement of marriage;

e. Disputes filed before the court after attempted non-court resolution through mediation with the assistance of a certified mediator registered in the local court but declared unsuccessful based on statements signed by the parties and certified mediators.

The phrase "excluded from liability" may be interpreted not as a prohibition, but may or may be done. As stated further in Article 4 paragraph (4) PERMA No. 1/2016: "based on the agreement of the parties, disputes that are excluded from mediation liabilities as referred to in paragraph (2) letter $a, c$, and $e$ shall still be resolved through voluntary mediation at the stage of examination of the case and level of remedy." The meaning of paragraph (2) letter $a$ according to Article 4 paragraph (4) is a dispute resolved through a Commercial Court procedure. Thus, jurisdictional mediation can be applied in the Commercial Court.

The empowerment of mediation in the Commercial Court as an enabling effort becomes an alternative option in addition to the peace set out in Article 144 and 222 of Act No. 37/2004. The peace submitted after the debtors declared bankrupt as stipulated in Ar- 
ticle 144 of Act No. 37/2004 is not an answer to the protection of debtors, because such peace does not eliminate the consequences of bankruptcy in effect. Peace should be proposed before the debtor has been given a decree of bankruptcy, so that the debtors' appeal is bankrupt with no consequences.

The desire to implement mediation in the Commercial Court as the policy and strategy of legal development contained in Presidential Regulation No. 2/2015 in particular the enforcement of civil law. The resolution of civil cases is done by encouraging the optimization of the mediation process in court and the simplification of civil procedure is expected to encourage the efficiency of civil matter resolution. It will also contribute positively to the improvement of the competitiveness of the national economy; hence it is necessary to adjust the legislation.

Mediation is very suitable to be applied for the dispute resolution because it contains the cultural values of a cooperative-spirited nation. Values of co-operative, compromise, and consensus deliberation are the hallmark of the Indonesian nation based on Pancasila. Moch. Faisal Salam, ${ }^{10}$ dispute resolution through $\mathrm{Al}$ ternative Dispute Resolution (ADR) develops in Indonesia not only because it is in line with the cultural values of the nation but it is seen as a advantageous opportunity of various factors, namely:

\section{Economic}

ADR has a potential as a more economical solution, both from the point of view of cost and time.

\section{Discussed Scope}

10 Moch Faisal Salam. 2007. Penyelesaian Sengketa Bisnis Secara Nasional dan Internasional. Cetakan 1. Bandung: Mandar Maju, page. 177.
ADR has an ability to discuss issues agendas more broadly, comprehensively and flexibly. This can happen because the rules of the game are developed and determined by the parties to the dispute in accordance with their interests and needs. It has the potential to resolve very complicated conflicts (polycentric) caused by the substance of cases with scientific problems.

\section{Good Relationship}

ADR that rely on cooperative resolution are best suited for those who emphasize the importance of fostering both ongoing and future relationships.

The Commercial Court is a court that places a strict time frame in bankruptcy resolution. Article 8 paragraph (5) of Act No. $37 / 2004$ states that "a court ruling on a request for bankruptcy statement shall be pronounced no later than 60 (sixty) days after the date of application for bankruptcy statement registered." Furthermore, in Article 24 paragraph (2) PERMA No. 1/2016 the mediation process shall take place no later than 30 (thirty days) from the commencement of the order to mediate.

Time frame of bankruptcy resolution in Act No. 37/2004 is one of the changes to provide certainty of time. It is described in Articles 4, 6, 8, 9, 10, 147, 152, 282 and 288 of Act No. 37/2004. This clear limitation of time frame which makes the basis of the liability exceptions first attempted to resolve through mediation in the Commercial Court, but mediation is not prohibited to continue to be implemented as long as there is agreement of the parties.

The implementation of mediation in the Commercial Court is the best solution that 
can be reached by the parties to reach a peace agreement without being overshadowed by the bankruptcy if there is no agreement as the peace within the framework of PKPU. If no agreement in mediation, then case investigation can be continued in the court according to the provisions of the law. Substantially the peace in the mediation procedure differs from the proposed peace plan after the debtor is declared bankrupt and the peace plan proposed within the framework of the PKPU.

The substance of peace as filed by the bankrupt debtors is a peace that aims to end the bankruptcy that has been decided by the Commercial Court. Article 151 of Act No. $37 / 2004$ states that "the proposed peace plan of a bankrupt debtor may be accepted if it is approved in a creditor meeting by more than $1 / 2$ (a half) the number of concurrent creditors present at the meeting and the right recognized or temporarily recognized, representing at least 2/3 (two thirds) of the total amount of recognized or recognized receivable receivables from the creditors of the cashier or their proxies present at the meeting." Voting of creditors to approve the bankruptcy debtors' peace plan is made twice (2). As the provisions of Article 152 paragraph (1) of Act No. $37 / 2004$ states that "if more than $1 / 2$ (a half) the number of creditors present at the creditor meeting and representing at least $1 / 2$ (a half) of the amount of creditors' receivables that have the voting rights agree to accept the peace plan then in the longest period 8 (eight) days after the first ballot was held, a second vote was held, without any calling required." Article 159 paragraph (2) of Act No. 37/2004 states that the court is obliged to reject the endorsement of peace if:

a. the debtor' property, including the object for which the exercise of the right to hold an object, far greater than the amount agreed upon in the peace;

b. the implementation of peace is not sufficiently secure; and/or

C. the peace is achieved by fraud or conspiracy with one or more creditors or because of the use of other dishonest attempts and regardless of whether the debtor or any other party cooperates to achieve this.

Furthermore, according to Article 160 paragraph (1) of Act No. 37/2004 states that if the endorsement of the peace is rejected, the bankrupt debtor may file an appeal, and the provision of Article 160 paragraph (2) of Act No. 37/2004 states that creditors who refuse approval of peace or creditors who agree to peace but when knowing that peace is achieved due to fraud or conspiracy with one or more creditors or because of the use of other dishonest attempts and regardless of whether the debtor or other party cooperates to achieve this, can make the cassation remedy.

The substance of peace within the PKPU's framework is a peace aimed at request extension of the term of debt repayment in the event that the debtor cannot or predict will not be able to continue repaying its debts in due date and can be collected. If this peace request is rejected then the debtor will be declared bankrupt, and there is no legal remedy available.

The substance in mediation is to reach a win-win solution between the parties assisted by a third party, not with a purpose to requesting extension of the pay period. A mediator is a judge or any other party who has a Mediator Certificate as a neutral party assisting the parties in the negotiation process to seek possible dispute resolution without resorting to the 
disconnection or enforcement of a resolution as set forth in Article 1 point 2 PERMA No. $1 / 2016$. Upon agreement of the parties and/or attorneys, the mediator may present an expert or more. In connection with mediation in the Commercial Court for bankruptcy resolution, the expert presented may be an accountant, i.e, a public accountant.

The idea to empower the mediation in bankruptcy cases is based on the weaknesses contained in the peace efforts as in Act No. $37 / 2004$. The merit of mediation is that the mediating debtor is not overshadowed by the bankruptcy if the agreement is not reached. Mediation is an excellent way to solve bankruptcy problems, especially if the debtor is in a position to have the ability to pay (prospectively). Debtor' assets are much larger than the total debt is the selling value that can be offered by debtors to support the success of mediation. The purpose of bankruptcy application filed by creditors is to get debt repayments that are not paid by the debtor even though the debtors' assets or assets exceeds the total amount of debt, either due to exeptio non adimpleti contractus factor, natural factors that make the debtor not paying. Debt repayment can be made to all creditors because the position of the property is sufficient to pay. The advantage that can be taken by both parties if they take this mediation path is that all creditors will be fulfilled the debt repayment, and the debtor is not bankrupt. Can be said of debtors who have the ability to pay, the resolution does not have to go through bankruptcy that resulted in all the confiscated property and reputation of the debtor company become damaged.

In relation to the period of mediation in the Commercial Court, it can be done as PKPUs period. Considering substantially be- tween mediation procedure and PKPU is different, it can be an alternative option that can be done by the debtor. Whether want to apply for PKPU, because they feel unable or will not be able to pay the debts that are due date or want to take mediation, because has the ability to pay all debts of creditors. Therefore, the period of mediation and PKPU can be flexibly used and not interfere with the time frame set in the resolution of bankruptcy and PKPU.

The advantage gained from dispute resolution through mediation in general is due to the flexibility of the parties in resolving the dispute, as seen in several mediation advantages, as follows:

1. Voluntary, the decision of mediation is submitted to the parties' agreement, so that a decision can be reached as the parties' wises;

2. Flexible, process or stage in the mediation is very flexible, even the parties can arrange their procedure to mediated;

3. Interest Based, in mediation is not sought who is right or wrong, but rather to safeguard the interests of each party;

4. Future Looking, mediation put forward to keep the relationship of the disputing parties forward and not oriented to the past;

5. Oriented Parties, with informal procedures, stakeholders can actively control the mediation process and take the resolution regardless of the assistance of a lawyer;

6. Parties Control, dispute resolution through mediation is a decision of each party. The mediator cannot impose to reach an agreement. ${ }^{11}$

11 Academic Paper of the Supreme Court. Op.Cit, page $\mathrm{xxi}$ 
The agreement of peace reached in mediation shall not contain provisions that are contrary to law, public order and/or morals, harm to third parties or cannot be implemented as regulated in Article 27 paragraph (2) PERMA No. 1/2016. A partial peace agreement as referred to in Part Five of PERMA No. 1/2016 cannot be applied in mediation in the Commercial Court. The agreement of peace can be submitted to the Court Judge to be reinforced in the Deed of Peace. At the latest 3 days, the Judge issues the stipulation of the day of the hearing to read the Deed of Peace. The deed of peace is a deed containing the content of the peace script and the verdict of judge that reinforces the agreement of peace. If the parties do not wish the Peace Agreement be reinforced in the deed of peace, the Peace Agreement shall contain the revocation of the petition for bankruptcy.

Example of revocation of request for bankruptcy statement by creditors due to peace:

1. PT. Richlands Logistics Indonesia and PT. Sentosasegara Mulia Shipping, revoked the petition of bankruptcy No. 16/ Pdt.Sus.Pailit/2016/PN.Jkt Pst, dated 18 May 2016 against debtor PT. Petroselat Ltd. The reason for the revocation that PT. Petroselat still has good prospects;

2. Creditor: Argo Capital BV and Argo Global Holding BV revoked the petition of bankruptcy against PT. Trans Pasific Petrochemical Indotama, dated 8 September 2011. The reason for the revocation, that PT Petrochemical is a strategic company that is pity if bankrupted;

3. Creditor: PT. Trijaya Anugerah Mulia revoked the petition of bankruptcy against PT. ISS Indonesia;
4. Creditor: Eko Santoso Busianto has revoked the petition of bankruptcy against PT. Berau Coal Tbk. Date 1 July 2015;

5. Creditor: Allied Ever Investment Ltd revoked the petition of bankruptcy against PT. Kertas Nusantara (2009).

The idea of mediation empowerment in the Commercial Court is a matter that can bring beneficial effects for both parties and in macro also affect the stability of the national economy.

Today, developments in the United States are very encouraging towards the utilization and empowerment of ADR, particularly mediation in bankruptcy resolution to accelerate the resolution, as well as maintaining fairness and efficiency. ${ }^{12}$

And also, in Japan, the mediation is very relevant applied in the cases of sumir. Chotei ${ }^{13}$ in Japan aims to avoid litigation and resolve disputes through mediation. According to Mas Achmad Santosa, Chotei as in Japan applied to the court of sumir is very relevant if applied in the Commercial Court, so there is a special division for the case of sumir. The simpler of

12 Lisa A. Lomax. 2003. Alternative Dispute Resolution in Bankruptcy: "Rule 9019 and Bankruptcy Mediation Program. Proceedings : Rangkaian Lokakarya Terbatas Hukum Kepailitan dan Wawasan Hukum Bisnis Lainnya: tentang Penyempurnaan Undang-Undang Kepailitan. Jakarta: PPH. page. 36.

13 Chotei is mediation. In Japan, the mechanism of Chotei in addition to beginning with a lawsuit later delegated to chotei, Chotei allowed directly without preceded by the lawsuit first. Chotei performed in Sumir Court. See Yoshiro Kusano. The Role of Wakai (Peace) and Chotei (Mediation) System In Japan, Paper in International Seminar in cooperation with Japan Indonesia Lawyers Association and Lambung Mangkurat University, Banjarmasin 11 September 2015. pages. 8-9. 
case the faster solved through ADR. ${ }^{14}$

Thus, to provide protection to prospective debtors by doing legal reform of bankruptcy includes the improvement of material and formal substance. Given the material and formal aspects of the bankruptcy legal system is a unified whole.

The concept offered in the framework of providing legal protection against prospective corporate debtors is to make the principle of business continuity as the soul in the norm to bankrupted the company, in this case then the concretization of this business continuity principle will give birth to the norms that protect the company's debtors by adding a stage checking event through mediation. Mediation as a good legal solution ${ }^{15}$ can protect various interests. According to Philippe Nonet, ${ }^{16}$ good law is a law that offers more than just procedural justice, but good law must be competent and fair, this kind of law should be able to recognize the public will and be committed to the achievement of substantive justice.

This means that the bankrupted debtor is debtor who is no longer economically able to pay the debts due to the condition of the

14 Mas Achmad Santosa, in Prosiding Mediasi. Op.Cit. pages 88-89.

15 Good law is a law that has 3 (three) behaviors at once; juridical, sociological and philosophical. A rule of law is juridical if the rule of law based on a higher level of law, and if the rule is established in the manner prescribed. A rule of law is sociological if the law is recognized or accepted by the public to whom the rule of law is addressed/enacted. A rule of law is philosophical if the rule of law is in accordance with the ideal of law (rechtidee) as the highest positive value, in accordance with Pancasila and the 1945 Constitution. Riduan Syahrani. Kata-kata kunci... Op. Cit., page 23.

16 Nonet, Philippe dan Philip Selznick. 2015. Hukum Responsif, terjemahan Raisul Muttaqin, Cetakan IX. Bandung: Nusa Media. Page. 84. company that has a negative intensity, and has also fulfilled the requirements of law, namely the fulfillment of elements have debt from more than one creditor who has due date and can be billed. Thus, the bankrupted debtor is a properly debtor bankrupt both in economic and legal terms.

The concept of legal reform in bankruptcy procedures in the Commercial Court can be interpreted as a real effort in reforming the values of bankruptcy law. Law renewal involves not only law substance renewal but also the substance of formal law. The concept of renewal is in line with the development of modern bankruptcy objectives such as in the United States and Britain that is directing the purpose of bankruptcy to a process to maximize the value of business continuity, maintaining the existence of business without bankrupt the debtor with potential and prospects in the future, protecting the interests of creditors on its bills.

\section{CONCLUSION}

A model of peace through mediation can resolve the issue of bankruptcy against prospective debtors. The outcome of mediation empowerment in the Commercial Court is an agreement between the debtor and the creditor to the company that still has the ability to develop in the future because the indicators that the company is potential and prospective, not bankrupt but given the occasion to continue its business, by not detach its liability to keep paying all debts to the creditors.

Mediation in the commercial court as a form of Indonesian bankruptcy legal renewal towards the development of modern bankruptcy is a step taken to create an equal in protection between creditors, debtors and other related parties. An equal protection between 
creditors and debtor that still has potential and prospect is growing shoots, so that the Indonesian economy becomes strong.

Mediation in the commercial court in accordance with policy and strategy of law development as contained in Presidential Regulation No. 2/2015 in particular the enforcement of civil law. The resolution of civil cases is done by encouraging the optimization of mediation process in the court and simplification of civil procedure is expected to encourage the efficiency of civil matter resolution and give contribution positively to the improvement of the national economy, therefore it is necessary to adjust the legislation.

\section{BIBLIOGRAPHY}

Witanto, D.Y. 2011. Hukum Acara Mediasi

Dalam Perkara Perdata Di Lingkungan

Perdailan Umum dan Peradilan Agama Menurut PERMA No. 1 Tahun 2008 Tentang Prosedur Mediasi Di Pengadilan. Bandung: Alfabeta.

Lomax, Lisa A. 2003. Alternative Dispute Resolution in Bankruptcy:Rule 9019 and Bankruptcy Mediation Program”. Proceedings: Rangkaian Lokakarya Terbatas Hukum Kepailitan dan Wawasan Hukum Bisnis Lainnya: tentang Penyempurnaan Undang-Undang Kepailitan. Jakarta: PPH.

Shubhan, M. Hadi. 2009. Hukum Kepailitan: Prinsip, Norma dan Praktik di Peradilan. Jakarta: Kencana Prenada Media Group.

Salam, Moch. Faisal. 2007. Penyelesaian Sengketa Bisnis Secara Nasional dan Internasional. Cetakan 1. Bandung: Mandar Maju.

Zulaeha, Mulyani. 2016. Konsep Kepailitan Yang Memberikan Perlindungan Hukum Terhadap Debitor Perusahaan Yang
Prospektif. Dissertation. Malang: Faculty of Law, Brawijaya University.

Nonet, Philippe dan Philip Selznick. 2015. Hukum Responsif. terjemahan Raisul Muttaqin, Cetakan IX. Bandung: Nusa Media.

Prosiding Mahkamah Agung RI. 2005. Mediasi dan Court Annexed Mediation. Jakarta: Mahkamah Agung RI dan Pusat Pengkajian Hukum.

Syahrani, Riduan. 2004. Buku Materi Dasar Hukum Acara Perdata. Bandung: Citra Aditya Bakti.

The Supreme Court R.I. 2005. Naskah Akademis Mahkamah Agung RI Tahun 2005 tentang Pembaharuan Sistem Peradilan. Jakarta: Mahkamah Agung RI.

Kusano, Yoshiro. The Role of Wakai (Peace) and Chotei (Mediation) System In Japan, Paper in International Seminar in cooperation with Japan Indonesia Lawyers Association and Lambung Mangkurat University, Banjarmasin 11 September 2015. 